\title{
THE SUPERVISION IN THE PROCESS OF INVESTIGATION AND INVESTIGATION OF CORRUPTION (POLICE AND PROSECUTION)
}

\author{
Fence M Wantu
}

Faculty of Law, Universitas Negeri Gorontalo, J1. Jend. Sudirman No.6, Dulalowo Tim., Kota Tengah, Kota Gorontalo, Gorontalo, Indonesia, 96128 E-mail: fence.wantu@yahoo.co.id

\section{Lusiana M Tijow}

Faculty of Law, Universitas Negeri Gorontalo, Jl. Jend. Sudirman No.6, Dulalowo Tim., Kota Tengah, Kota Gorontalo, Gorontalo, Indonesia, 96128

E-mail: usianamtijow@gmail.com

\section{Nasruddin Yusuf}

Faculty of Sharia, Institut Agama Islam Negeri Manado, Sulawesi Utara, Indonesia, Jl. Dr. S.H. Sarundaiang Kawasan Ring Road I Kota Manado, 95128 E-mail: nasruddin.yusuf@iain-manado.ac.id

\begin{abstract}
The investigation process is an integral part of the investigation. Put merely, and the research is an essential part of the study. The emphasis of investigations is on finding and gathering evidence so that the criminal act found becomes apparent and can find the culprit. In principle, the analysis of a criminal case is a continuation of the research carried out previously. For an event that has been declared a criminal act by the investigator, the next step is to investigate who the perpetrator of the crime is. This research was conducted by examining field data. This writing is to provide an ideal concept of supervision in the process of suspected criminal acts and then goes to the supervision of the investigation process. The investigation is carried out by officials appointed by Law as referred to in applicable laws and regulations. Still, management needs to be carried out by all parties, including the community. This management is a fundamental affirmation that all stakeholders play a significant role in eradicating corruption that threatens society's stability and security and weakens the institutions and values of democracy and justice, endangers sustainable development and law enforcement.
\end{abstract}

Keywords: Supervision; Corruption; Police; Prosecution; Gorontalo Province

How to Cite: Wantu, F. M., Tijow, L. M., Yusuf, N. (2020). The Supervision in the Process of Investigation and Investigation of Corruption (Police and Prosecution). Jurnal Ilmiah Al-Syir'ah, 18(2), 140-155.

Permalink/DOI: http://dx.doi.org/10.30984/jis.v18i2.1257

Copyright ( 2020, Jurnal Ilmiah Al-Syir'ah

The Supervision in the Process of Investigation and Investigation of Corruption (Police and Prosecution) Fence M Wantu, Lusiana M Tijow, Nasruddin Yusuf 


\section{INTRODUCTION}

Corruption is a severe problem in many countries. The seriousness of the development of degeneration has threatened the national and international community's stability and security, weakened the institutions and values of democracy and justice, and endangered sustainable development and law enforcement (Atmasasmita, 2003). Based on research conducted by Political and Economic Risk Consultancy (PERC) since 2005, Indonesia has been in the first rank of the most corrupt country in Asia. Transparency International has also given a similar predicate, which has always put Indonesia as the most corrupt country in the world (Isra \& Hiariej, 2010).

In Indonesia, the criminal act of corruption has developed in terms of form, type, and crime mode. The development of degeneration also occurred the number of state losses incurred due to criminal acts of corruption in 2010, around 3.6 trillion (CyberNews, 2011). Based on the General Explanation of Law No. 30 of 2002 concerning the Corruption Eradication Commission (from now on referred to as the KPK Law), the criminal act of corruption has undergone a shift. Corruption was an ordinary crime class; now, corruption is classified as an extraordinary crime.

This shift has consequences in prosecuting criminal acts of corruption. In taking action against criminal acts of corruption, the Indonesian government makes efforts deemed necessary to deal with criminal acts of corruption, such as establishing the Corruption Eradication Commission (KPK) and ratification of several international conventions related to crime.

Efforts to eradicate corruption are the primary plan that must be realized immediately. These efforts must be preventive and repressive. The two steps must be executed properly and can be synergistic or likened to one coin's two sides. Without any preventative measures, repressive efforts will fail in carrying out their mission. Likewise, on the other hand, without matters of a repressive nature, preventive actions are mere nonsense.

In implementing repressive measures, as is the case with criminal law enforcement in Indonesia, it is known that there are stages that must be passed by law enforcers to carry out their duties. The initial stages that must be passed by law enforcers are the investigation and investigation stages. Based on article 1 point (5) of the Criminal Procedure Code, what is meant by an investigation is a series of actions by an investigator to search for and find out an event that is suspected to be a criminal act to determine whether or not an investigation can be carried out in a manner regulated by Law. In number (3) of the same article, it is stated that an investigation is a series of actions by an investigator in terms, according to the manner regulated in this Law and collect evidence which with that evidence sheds light on the criminal activity has occurred and found the suspect. The subject (perpetrator) of the two definitions of investigation and investigation is the investigator and investigator. In prosecuting criminal acts of corruption in

The Supervision in the Process of Investigation and Investigation of Corruption (Police and Prosecution)

Fence M Wantu, Lusiana M Tijow, Nasruddin Yusuf 


\section{Jurnal Ilmiah Al-Syir'ah Vol. 18, No. 2 (2020): 140-155 \\ Website: http://journal.iain-manado.ac.id/index.php/JIS ISSN 2528-0368 (online) ISSN 1693-4202 (print)}

Indonesia, the Police and the Attorney General's Office do not have a clear division regarding the criminal act of corruption, which is their respective authority.

The investigation process is an integral part of the investigation. Simply put, the analysis is an inseparable part of the study. Law No. 8 of 1981 on the Criminal Procedure Code provides legal certainty in the law enforcement process to determine a person who commits an act that qualifies to be a criminal act based on minimal preliminary evidence. 2 (two) pieces of evidence.

The investigation emphasizes finding and gathering evidence so that the criminal act found becomes transparent and can find the perpetrator. It can be said that the investigation and investigation are a series of two phases of activity that are interrelated (Askin \& Cahaya, 2008). Investigating a criminal case is, in principle, a continuation of an earlier investigation. For an event that has been declared a criminal act by an investigator, the next step is to investigate who the crime perpetrator is (Rukmini, 2006).

The Police can carry out the investigation and investigation process, but corruption can be carried out by the Prosecutor's office in a particular crime. The Attorney General's Office has the authority to conduct investigations into cases of criminal acts of corruption that cannot be fully understood. Following the fact in judicial practice, some courts cannot accept that prosecutors have the authority to investigate criminal acts of corruption, namely PN Ciamis (Interlocutory Court District Court) Ciamis West Java on June 11, 2003 Number 125 / Pid BK / 2003 / PN. Cms who acquitted the defendant in the case on behalf of the defendant Jamaluddin because the Prosecutor's office was not authorized to investigate corruption crimes.). The decision of the Ciamis District Court caused tremendous legal turmoil, and finally, through the Bandung West Java High Court Decision made a Decision Number: I95 / Pid / 2003 / PT.BDG, dated October 14, 2003, the trial process was reopened. This decision means that the Ciamis District Attorney has the authority to prosecute the suspect.

The consequence of this fact is that there is no information or news through the media. Almost every district court in Indonesia has received pretrial submissions related to this matter. Even after the Ciamis District Court's decision in various regions has tried to question almost the same thing through recommendations. Pretrial for various legal reasons. One of them is the submission of pretrial at the Boalemo District Court related to the suspect's determination, which, according to the applicant, was not preceded by the decision of an impressive spring for the suspect.

For this reason, the process of updating the handling of criminal cases is an effort that needs to be improved. Barda Nawawi Arief (2010) states that criminal law reform essentially contains meaning. An effort to reorient and reform criminal Law following the central values of Indonesian society's sociopolitical, sociophilosophical, and socio-cultural values underlie social policies, illegal policies, and policies Law enforcement in Indonesia. In short, it can be said that criminal law

The Supervision in the Process of Investigation and Investigation of Corruption (Police and Prosecution) Fence M Wantu, Lusiana M Tijow, Nasruddin Yusuf 
reform must be pursued with a policy-oriented approach and a value-oriented approach.

By considering the matters mentioned above, what needs to be done is supervising the process, starting from investigating and investigating corruption. The investigation and investigation process is not based solely on an assessment of subjectivity but on an objective evaluation. They are considering the need to conduct analysis and legal assessment of investigations and investigations into corruption cases. The formation and implementation of preventive strategies are directed at the causes of corruption. A detective strategy is made and directed so that if an act of corruption has already occurred, then the act will be known early on in the shortest time possible and as accurately as possible to be followed up appropriately. Meanwhile, a repressive strategy was created and implemented to provide legal sanctions, which are rewarded quickly and appropriately to the parties involved in corruption.

\section{RESEARCH METHODS}

This research was conducted by examining field data, primary data, or field research (Nasution, 2008). As a follow-up to this field research and to perfect the data obtained from field research (Mertokusumo, 2010), the research was conducted at Polda Gorontalo and the District Prosecutor's Office in Gorontalo Province. The collection materials in the form of literature and books, journals were used as a theory in this research.

The data used in this study is a qualitative descriptive analysis so that a comprehensive picture can be obtained of the methods related to the subject matter. In this case, Soerjono Soekanto (2001) states that a qualitative approach is actually a research method that produces descriptive data.

\section{RESULTS AND DISCUSSION}

\section{Investigation and Investigation Arrangements in the Prevailing Laws}

Corruption is a type of crime that is categorized as a form of white-collar crime. This type of crime is a crime committed by an honorable person who has a high social status and is committed in the framework of his job, generally constituting a breach of trust. Other definitions of white-collar crime include the following: crimes committed by people sitting behind the table, crimes committed by people of the same rank, crimes committed by knowledgeable people, interpreted as the opposite of the word "crime using force Or "street crime", crimes committed with sophisticated technology, crimes that are not conventional; committed by people who have the expertise or have knowledge of advanced technology and hidden crimes.

Therefore, disclosing cases of this type of crime is different from revealing conventional crimes. White-collar criminals tend to come from circles that have a 


\section{Jurnal Ilmiah Al-Syir'ah Vol. 18, No. 2 (2020): 140-155 \\ Website: http://journal.iain-manado.ac.id/index.php/JIS ISSN 2528-0368 (online) ISSN 1693-4202 (print)}

high intellectual level. With the ability they have, white-collar criminals will be able to carefully calculate all the possibilities that may occur in connection with the crimes they have committed. The main objective is to obscure or cover up so that his actions are not exposed and examined by law enforcement officials.

As a result, in disclosing white-collar crime cases, law enforcement officers have to work extra hard compared to conventional crime disclosure. It seems as if the law enforcement apparatus must first collide with the criminals' intelligence and ingenuity. This condition also occurs in the exposure of corruption. In addition to having a high intellectual level, usually the perpetrators of corruption are close parties or even have the power and strength to commit corruption in an organized and closed manner.

When law enforcement officials intend to initiate a law enforcement process that begins with an investigation into a criminal act of corruption, then the perpetrators of corruption will also start to fight against these efforts. This resistance can take the form of losing evidence, influencing witnesses, forming an opinion in the public that he is innocent.

Nationally, the government has created a National Corruption Eradication Strategy (SNPK) based on 4 (four) approaches the traditional approach, the cultural approach, the economic approach, and the human resources approach. From a legal perspective, many laws and regulations regulate the eradication of corruption in Indonesia. According to Ramelan (2004), if it is observed in every consideration or general explanation of the Law. At any change or amendment of the Law, it is essentially based on the review that corruption has caused many losses to the country's finances and economy. The existing rules are no longer effective in eradicating acts. Increasing and complex corruption crimes.

Following the emphasis on the direction of integration and synergy of legal reform policies, the investigation and investigation process is part of this. The Criminal Procedure Code has regulated the investigation and investigation process arrangements, and laws and regulations, namely the Attorney General's Office, the Police, and the KPK, and are in Standard Operating Procedures (SOP) from respective law enforcement agencies.

We still remember the alleged corruption case in the form of embezzlement of funds to secure the election for the governor in West Java amounting to 8 billion; at that time, the former West Java Police Chief (Susno Duaji) was suspected of being involved in the act (Mad, 2010). The handling of criminal acts of corruption in the form of embezzlement of the governor's election security funds occurred claims between the West Java Regional Police and the West Java High Court, which felt the most entitled to handle the corruption case.

Likewise, what happened between the KPK and the Police (Cicak versus Buaya) was an argument that had the most right to handle corruption cases, bribery of KPK members (NRL, 2013). This case is so long and quite draining the nation's

The Supervision in the Process of Investigation and Investigation of Corruption (Police and Prosecution) Fence M Wantu, Lusiana M Tijow, Nasruddin Yusuf 
great energy. It even spreads from the process of handling the alleged bribery case at the Ministry of Forestry, followed by the alleged involvement of the then KPK chairman, Antasary Ashar, over the death of Nazarudin, then the Century bailout case.

The three institutions can understand where authority roles and positions are exercised following the laws governing the Police, Attorney General's Office, and the KPK. The Police Institution is subject to the rules of Police Law No. 2 of 2002 concerning the Indonesian National Police. Likewise, Law Number 16 of 2004 concerning the Attorney General's Office of the Republic of Indonesia regulates the process of investigating and investigating criminal acts of corruption as handled in Article 30 paragraph (1) letters d and e. Likewise, Law Number 30 of 2002 concerning the Corruption Eradication Commission also has duties and authority in handling corruption crimes.

Claims of authority from each law enforcement agency that has the right to handle corruption crimes, starting from the investigation and investigation process, should not dampen the spirit in the context of eradicating corruption. The principle of handling criminal acts, including the investigation and investigation of criminal acts of corruption, is an inseparable part of the source of procedural Law as regulated in Law No.8 of 1981. Ideally, Law No. 8 of 1981 concerning the Criminal Procedure Code placed as the most above all norms, even though the respective law enforcers of the Police, Attorney General's Office, and the Corruption Eradication Commission have the authority regulated in their laws and regulations.

The Law that regulates each law enforcer's authority should not be placed as a specification of the applicable criminal procedural Law. Such a condition, if it follows one of the relevant legal principles that states that a special provision overriding the general provision or lex specialis derogate lex generalis, cannot be treated in the case of the conditions stipulated in the Criminal Procedure Code.

The alleged corruption case submitted by the Tilamuta Boalemo District Attorney, namely cases No. 7 / Pid.Sus-TPK / 2020 / PN.TMT, which was then submitted pretrial by the suspect's attorney, became concrete evidence of weak administration in investigating and investigating corruption crimes. . The main object of submitting a court paper is none other than the time of the initial determination as investigated. Suddenly becoming a suspect with the pretrial petitioner's argument that the District Attorney Tilamuta Boalemo has never issued a special Order (Sprindik) even though it has previously issued a general warrant (Sprindik).

The argument debate in pretrial (Ismail \& Tamu, 2009) is quite impressive. Of course, through their attorney against the defendant, each petitioner, in this case, the Public Prosecutor's Office Tilamuta Boalemo has arguments following their respective interpretations. Through his attorney, the applicant stated that the investigation and investigation process carried out by the Tilamuta District Attorney, especially the determination or determination of the investigated witness

The Supervision in the Process of Investigation and Investigation of Corruption (Police and Prosecution) Fence M Wantu, Lusiana M Tijow, Nasruddin Yusuf 
(their client) to be a suspect and the defendant was not following the criminal procedure law mechanism. The initial examination of an investigated witness who was suddenly turned into a suspect without notification was deemed to have violated the criminal procedure law's provisions, especially the SOP of the Prosecutor itself.

The Boalemo District Attorney stated that the investigation and investigation process followed the applicable provisions, especially the Criminal Procedure Code. The investigated witness's initial determination to be a suspect notified the person concerned. However, the notification letter was given at the address where the witness was examined (Boalemo Regional Government Office). The suspect's determination letter had been delivered to the house. Still, no one received it directly to the place-work of the concerned.

These different arguments are not wrong, but several notes should be considered in the future. The things of concern to learn from submitting pretrial applications related to the process of investigation and investigation into alleged corruption in the Boalemo Government are as follows: (1) Meanwhile, the defendant (Attorney General Boalemo) carried out the investigation and investigation process in accordance with the Criminal Procedure Code. This investigation is not wrong because KUHAP is the highest legal basis in criminal proceedings; (2) whereas the Petitioner (Tim Adipati W et al.) Questioned the SOP applied within the Prosecutor's Office did not go well. Whereas so far, the AGO in determining the process of investigating and investigating suspected criminal acts of corruption guided by its environmental SOP. What the petitioner is questioning is not wrong. Still, the defendant party, in this case, the Boalemo District Attorney, should not be considered wrong because they base on the investigation and investigation process following KUHAP; (3) Whereas what the defendant did by the Boalemo District Attorney is a question mark that must be answered because in cases such as alleged corruption, the Prosecutor usually bases everything through the KUHAP and SOP in their environment. This KUHAP caused a polemic and question by the petitioner; (4) In the end, the pretrial verdict rejected the petitioner's petition. The single pretrial judge stated that what the respondent had done was following the applicable Law, namely the Criminal Procedure Code.

Based on the case, the problems arising from the investigation and investigation process do not end up like this and include the issue of who has the most right to handle the alleged corruption crime. An example of alleged corruption in the use of village funds is in a village in the Gorontalo District, where the investigation and investigation process involves the Police, in this case, the Limboto Police and the Limboto District Attorney. Initially, each of these institutions felt that they had the most authority over handling this case, but based on directions from their superiors. In this case, the Gorontalo Police and the Gorontalo High Court, this process was finally handled together, namely at the investigation stage by the Limboto Police, then the investigation stage for the Limboto Police and the Attorney General's Office. Limboto District, then prosecution by the Limboto Public Prosecutor.

The Supervision in the Process of Investigation and Investigation of Corruption (Police and Prosecution) Fence M Wantu, Lusiana M Tijow, Nasruddin Yusuf 


\section{Jurnal Ilmiah Al-Syir'ah Vol. 18, No. 2 (2020): 140-155 \\ Website: http://journal.iain-manado.ac.id/index.php/JIS ISSN 2528-0368 (online) ISSN 1693-4202 (print)}

The consequences of the debate over who has the right to handle suspected criminal acts of using village funds have the following impacts: (1) It is unlikely that the criminal act of corruption in the use of village funds will begin to handle it if each institution is still debating its authority; (2) This debate over authority causes the party who is suspected of a criminal act of corruption to feel happy because the case does not begin the investigation and investigation process; (3) Alleged criminal acts of corruption are pending and unfinished cases; (4) Public trust in the two institutions is not good; (5) The law enforcement process seems to be running in place; (6) Legal certainty and justice are no longer upheld.

In the Criminal Procedure Code, investigative authority falls to the Indonesian Police. Article 6 of the Criminal Procedure Code states that investigators are State Police Officers of the Republic of Indonesia. This procedure means that the Police are the sole investigators in the Criminal Procedure Code. In the transitional rules of Article 284 paragraph (2) of the Criminal Procedure Code, it is stated that within two years after this Law is promulgated, all cases will apply the provisions of this Law, with temporary exceptions regarding the special requirements of criminal procedures as mentioned in specific laws. Until there is a change and it is declared no longer valid.

Law Number 16 of 2004 concerning the Prosecutor's office explicitly states that the Prosecutor's office has the authority to investigate criminal acts of corruption. This Law is regulated in Article 30 paragraph (1) letter d, namely investigating certain criminal acts. In his explanation, it is stated that what is meant by certain crimes are criminal acts of corruption and human rights violations. With the sound of Article 30 paragraph (1) letter d Law Number 16 of 2004, the judiciary formally has the authority to investigate criminal acts of corruption and human rights violations.

In the Indonesian criminal justice system, the position of the Prosecutor has a central role. The power to determine whether a case can be continued or not at trial based on valid evidence is Dominus by the Indonesian Prosecutor's office. The Attorney General's Office in investigating and investigating a case must be involved, so it is not limited to case files sent by Police investigators to be examined by the Prosecutor. In this way, the Prosecutor will find it challenging to direct a case towards collecting sufficient evidence to try cases before the court.

Furthermore, Government Regulation number 27 of 1983 in Article 17 explicitly states the Prosecutor's office as the investigator for individual criminal acts (corruption). For more details, the contents of the article are as follows: "Investigators according to the special provisions of the criminal procedure as referred to in specific laws as referred to in Article 284 paragraph (2). The Criminal Procedure Code is carried out by Investigators, Prosecutors, and other authorized Investigator officials based on statutory regulations.

Based on the description above, the regulations regarding the investigation and investigation process in statutory regulations are not only in the Criminal

The Supervision in the Process of Investigation and Investigation of Corruption (Police and Prosecution)

Fence M Wantu, Lusiana M Tijow, Nasruddin Yusuf 
Procedure Code, but also in other laws and regulations, especially those in the police law and the Prosecutor's Law, but also governed by government regulations. It is also included in the respective Standard Operating Procedures (SOP), be it the Police, the Prosecutor's office, or the KPK. Ideally, each of these regulations should not create conflicting conditions but should complement each other in handling corruption crimes. Each principle's substance does not indicate that one of the laws and rules feels the most superior or powerful. However, it turns out that the interpretation in the field causes the difference in its implementation. This principle should not be left for too long because corruption must continue and be maximized.

\section{Supervision of Investigations and Investigations at the Gorontalo Police and Prosecution Office}

Supervision is a form of mindset and action pattern to provide understanding and awareness to someone or several people. Who are assigned tasks to be carried out using various available resources correctly and adequately so that errors and irregularities can create losses by the institution or the organization concerned?

Supervision of investigations internally at the Police must run following the applicable provisions, the implementation of which starts from the time there is a public report regarding an alleged criminal act. The next monitoring process is carried out by ensuring that each stage of the investigation runs according to the provisions.

Supervision of the investigation and investigation process at Polda Gorontalo is currently by way of inventorying every incoming police report and classifying the case's level of difficulty, both reports at the Polda itself and each Polres even up to the Polsek level. Furthermore, suppose there is a complaint from the public. In that case, an investigation will be carried out regarding the alleged violation of the investigation and investigation process or maladministration practice by forming an investigative audit team to test the complaint's truth. The results of the investigative audit by the Gorontalo Regional Police are given a reply letter to the community or institution that submits complaints regarding the investigation findings. This investigation is based on examples of cases reported by the community. The handling has not been completed due to local officials' involvement, the complaint Boalemo, who said the Regent of Boalemo for a crime.

The scope of the research at Polda and Polres in the Gorontalo Province area found several indications. The supervision of investigations by investigating supervisory officials was not optimal. There were still complaints from the public regarding investigators' and assistant investigators' performance submitted to the Reskrim Unit and Propam Polda Gorontalo. Based on this, it is known that several factors cause weak supervision, namely: (1) The integrity factor of the investigating apparatus and investigating supervisory officials; (2) Legal factors as outlined in written regulations which are the basis for investigating supervisory officials; (3) The factor of the lack of officials carrying out the investigative supervision function; (4) The factor of applying sanctions that has not provided a deterrent

The Supervision in the Process of Investigation and Investigation of Corruption (Police and Prosecution) Fence M Wantu, Lusiana M Tijow, Nasruddin Yusuf 


\section{Jurnal Ilmiah Al-Syir'ah Vol. 18, No. 2 (2020): 140-155 \\ Website: http://journal.iain-manado.ac.id/index.php/JIS ISSN 2528-0368 (online) ISSN 1693-4202 (print)}

effect and has become a deterrent so that the same cases of maladministration are not repeated.

In fact, the Chief of Police Regulation number 14 of 2012 concerning Criminal Investigation Management indeed regulates the Investigation Process's General Provisions, including the basic principles of investigation and the management of studies to evaluate investigative performance assessments. The fact is that there are still deficiencies in it, namely that it has not been able to accommodate the procedures for supervising the investigation process and assigning such supervisory assignments to specific positions.

One of the obstacles faced by the police institution in supervising the investigation and investigation process so that maladministration does not occur can also be overcome by improving investigators' integrity. The investigator's integrity greatly determines the investigation and investigation process results following applicable regulations and, of course, respect for human rights.

For this reason, to improve the integrity of law enforcement officers, in this case, the Police investigators in the Gorontalo Regional Police, an absolute requirement that everyone, especially law enforcement officers, must-have, namely improving one's quality. To increase mental integrity and quality can be done in the following ways: First, increasing faith and devotion to God Almighty; Second, try to always think positively; Third, don't stop learning; Fourth, trying to make other people happy by increasing empathy for others; Fifth, be honest with yourself and others.

The supervision carried out by the Prosecutor's Commission, in general, produces an output in the form of recommendations for the Attorney General to be followed up by the Deputy Attorney General for Supervision as the internal supervisor at the AGO. Based on the fact of this process, it can be seen that the Prosecutor's Commission is waiting for follow-up investigations conducted by the Deputy Attorney General for Supervision. It is seen from this recommendation that it is not binding for the Prosecutor's office, and there is also no sanction. Also, the coordination and synchronization between the Attorney General's Commission and the ranks of the Deputy Attorney General for Supervision need to be improved so that the follow-up information on complaints reports and their resolutions can be appropriately updated. This resolution is a weakness that must be corrected so that the AGO's supervision can run more effectively in the future.

Based on research obtained from the High Prosecutor's Office, the form of supervision has been carried out; however, there is still an investigation and investigation process that does not follow the regulations. This investigation occurs because investigators both in the Police and prosecutors are not careful in handling cases, especially in determining two evidence as a condition for a criminal act. Delays in the investigation and investigation process, including case cases that have never complete, are examples found in handling criminal cases, especially at the level of investigation and investigation. Criminal cases starting from the

The Supervision in the Process of Investigation and Investigation of Corruption (Police and Prosecution)

Fence M Wantu, Lusiana M Tijow, Nasruddin Yusuf 


\section{Jurnal Ilmiah Al-Syir'ah Vol. 18, No. 2 (2020): 140-155 \\ Website: http://journal.iain-manado.ac.id/index.php/JIS ISSN 2528-0368 (online) ISSN 1693-4202 (print)}

investigation and investigation process by the police agency did not run optimally. This investigation can be seen in long handling, especially determining the suspect.

An example of handling corruption in the Tilamuta District Prosecutor's Office turns out to be in the process of investigation and investigation into problems because the determination of someone who was a suspect is considered not following the procedure. This investigation can prove by filing a pretrial application submitted to the Tilamuta District Court related to the suspect's determination in the alleged corruption of agricultural equipment in the Boalemo Regency.

In principle, Indonesia adheres to an integrated law enforcement system (Integrated Criminal Justice System), which is the Criminal Procedure Code's legal spirit. This integration is philosophically an instrument to realize the national goals of the Indonesian nation formulated by The Founding Father in the 1945 Constitution, namely protecting the community (social defense) to achieve social welfare (Atmasasmita, 1995).

The integrated law enforcement system based on the Criminal Procedure Code adheres to the principle of division of functions or a compartment system. Namely separating the duties and powers of prosecution and investigation in the judicial process and implementing integrated court decisions and - leading to an integrated criminal justice system (integrated criminal justice system decisions). However, in practice, there is no synergy between related agencies (Atmasasmita, 1995).

In the context of ideal supervision of the investigation and investigation process, of course, it cannot be separated from the community's role. The hope of community involvement in investigating and investigating criminal acts of corruption is beneficial for the realization of law enforcement. At least it can minimize or reduce the increasing number of corruption crimes.

The legitimacy of the role and involvement of the community can be seen in the provisions of Article 1 paragraph (2) of the Government Regulation of the Republic of Indonesia Number 68 of 1999 concerning Procedures for Implementing Community Participation in State Administration states that what is meant by community participation is the active role of the community to participate in realizing State administration that is clean and free from KKN which is carried out in accordance with legal, moral and social norms that apply in society.

In principle, the community's role in monitoring the handling of corruption crimes, including the investigation and investigation process at the Gorontalo District Attorney General's Office, is intended in general to improve the effectiveness of prevention and eradication of corruption. Apart from that, public participation in the supervision of criminal acts of corruption, especially in the investigation and investigation process, is nothing but to maintain the operation of handling cases of corruption cases thoroughly. Furthermore, in the context of legal protection and fulfilling a sense of justice, supervision of the handling of corruption

The Supervision in the Process of Investigation and Investigation of Corruption (Police and Prosecution) Fence M Wantu, Lusiana M Tijow, Nasruddin Yusuf 
crimes, including in the case of investigations and investigations, is nothing but to guard against arbitrary actions by law enforcers in determining perpetrators of corruption.

Supervision is a form of mindset and action pattern to provide understanding and awareness to someone or several people. Who are assigned tasks to be carried out using various available resources properly and adequately so that errors and irregularities do not occur that can cause harm to society: institution or organization.

Supervision of investigations internally at the Police must be carried out following the prevailing regulations, the implementation of which starts from the existence of a public report regarding an alleged criminal act, then the subsequent surveillance process is carried out by ensuring that each stage of the investigation runs according to the provisions.

The implementation of supervision of the investigation and investigation process at Polda Gorontalo is currently by way of inventorying every incoming police report and classifying the case's level of difficulty, both those in the Polda itself and each Polres even at the Polsek level. Furthermore, suppose there is a complaint from the public. In that case, an investigation will be carried out regarding the alleged violation of the investigation and investigation process or maladministration practice by forming an investigative audit team to test the complaint's truth. The results of the investigative audit by the Gorontalo Regional Police are given a reply letter to the community or institution that submits complaints regarding the investigation findings. Based on examples of cases reported by the community because the handling has not been completed due to local officials' involvement, such as a complaint on behalf of the Boalemo community who reported the crime of the Boalemo Regent.

The research scope at Polda and Polres in Gorontalo Province found several indications that the supervision of investigations by investigating supervisors was not optimal. There were still complaints from the public regarding investigators, and assistant investigators' performance was submitted to Reskrim and Propam. Gorontalo Civil Service Police Unit. Based on this, it is known that several factors cause weak supervision, namely: (1) The integrity factor of the investigating apparatus and investigating supervisory officials; (2) Legal factors as outlined in written regulations which are the basis for investigating supervisory officials; (3) The factor of the lack of officials carrying out the investigative supervision function; (4) The factor of applying sanctions that has not provided a deterrent effect and has become a deterrent so that the same cases of maladministration are not repeated.

In fact, the Chief of Police Regulation number 14 of 2012 concerning Criminal Investigation Management has indeed been regulated regarding the Investigation Process's General Provisions, including the basic principles of investigation and the management of studies to evaluate investigative performance assessments. The fact is that there are still deficiencies in it, namely that it has not 


\section{Jurnal Ilmiah Al-Syir'ah Vol. 18, No. 2 (2020): 140-155 \\ Website: http://journal.iain-manado.ac.id/index.php/JIS ISSN 2528-0368 (online) ISSN 1693-4202 (print)}

been able to accommodate the procedures for supervising the investigation process and assigning such supervisory assignments to specific positions.

One of the police institution's problems in supervising the investigation and investigation process to avoid maladministration can also be resolved by increasing the investigator's integrity. The investigator's integrity greatly determines the investigation and investigation process results following applicable regulations and, of course, respect for human rights.

For this reason, to improve the integrity of law enforcement officers, in this case, the Police investigators in the Gorontalo Regional Police, an absolute requirement that everyone, especially law enforcement officers, must-have, namely improving one's quality. To increase mental integrity and quality can be done in the following ways: First, growing faith and devotion to God Almighty; Second, try always to think positively; Third, don't stop learning; Fourth, trying to make other people happy by increasing empathy for others; Fifth, be honest with yourself and others.

The supervision carried out by the Prosecutor's Commission, in general, produces an output in the form of recommendations for the Attorney General to be followed up by the Deputy Attorney General for Supervision as the internal supervisor at the AGO. Based on the fact of this process, it can be seen that the Prosecutor's Commission is waiting for follow-up investigations conducted by the Deputy Attorney General for Supervision. It is seen from this recommendation that it is not binding on the Prosecutor's office, and there is also no sanction. Also, the coordination and synchronization between the Prosecutor General's Commission and the ranks of the Deputy Attorney General for Supervision need to be improved so that the follow-up information on complaints reports and their resolutions can be appropriately updated. A weakness that must be corrected so that the AGO's supervision can run more effectively in the future.

Based on research obtained from the High Prosecutor's Office, the form of supervision carry out; however, there is still an investigation and investigation process that is not following the regulations. The occurs because investigators both in the Police and prosecutors are not careful in handling cases, especially in determining two evidence as a condition for a criminal act. Delays in the investigation and investigation process, including case cases that have never been completed, are examples found in the handling of criminal cases, especially at the level of investigation and investigation. Criminal cases starting from the investigation and investigation process by the police agency did not run optimally. This can be seen in long handling, especially determining the suspect.

An example of handling corruption in the Tilamuta District Prosecutor's Office turns out to be in the process of investigation and investigation into problems because the determination of someone who was a suspect is considered not following the procedure. This can be proven by filing a pretrial application

The Supervision in the Process of Investigation and Investigation of Corruption (Police and Prosecution) Fence M Wantu, Lusiana M Tijow, Nasruddin Yusuf 


\section{Jurnal Ilmiah Al-Syir'ah Vol. 18, No. 2 (2020): 140-155 \\ Website: http://journal.iain-manado.ac.id/index.php/JIS ISSN 2528-0368 (online) ISSN 1693-4202 (print)}

submitted to the Tilamuta District Court related to the suspect's determination in the alleged corruption of agricultural equipment in the Boalemo Regency.

In principle, Indonesia adheres to an integrated law enforcement system (Integrated Criminal Justice System), which is the Criminal Procedure Code's legal spirit. This integration is philosophically an instrument to realize the national goals of the Indonesian nation formulated by The Founding Father in the 1945 Constitution, namely protecting the community (social-defense) to achieve social welfare.

The integrated law enforcement system based on the Criminal Procedure Code that we have so far adheres to the principle of division of functions or a compartment system, namely the separation of duties and powers for prosecution and investigation in the judicial process and the implementation of integrated court decisions. Decisions were leading to an integrated criminal justice system. (integrated criminal justice system), but in practice, there is no synergy between related institutions.

In the context of ideal supervision of the investigation and investigation process, of course, it cannot be separated from the community's role. The hope of community involvement in investigating and investigating criminal acts of corruption is beneficial for the realization of law enforcement. At least it can minimize or reduce the increasing number of corruption crimes.

The legitimacy of the community's role and involvement can be seen in the provisions of Article 1 paragraph (2). The Government Regulation of the Republic of Indonesia Number 68 of 1999 concerning Procedures for Implementing Community Participation in State Administration states. That what is meant by community participation in the community's active role in realizing State administration that is clean and free from $\mathrm{KKN}$, which is carried out in compliance with legal, moral and social norms applied in society.

In principle, the community's role in monitoring the handling of corruption crimes, including the investigation and investigation process at the Gorontalo District Attorney General's Office, is intended in general to improve the effectiveness of prevention and eradication of corruption. Apart from that, public participation in the supervision of criminal acts of corruption, especially in the investigation and investigation process, is nothing but to maintain the operation of handling cases of corruption cases thoroughly. Furthermore, in the context of legal protection and fulfilling a sense of justice, supervision of the handling of corruption crimes, including in the case of investigations and investigations, is nothing but to guard against arbitrary actions by law enforcers in determining perpetrators of corruption. 


\section{CONCLUSION}

The regulations regarding the process of investigation and investigation in statutory regulations are in the Criminal Procedure Code and other laws and regulations, especially those in the police law and the Prosecutor's Law, but are also regulated by government regulations. It is also included in the respective Standard Operating Procedures (SOP), be it the Police, the Prosecutor's office, or the KPK. These regulations do not create conflicting conditions but should complement each other in handling corruption crimes. Each regulation's substance does not indicate that one of the laws and rules feels the most superior or powerful. However, it turns out that the interpretation in the field causes the difference in its implementation.

Ideally, the supervision of investigations and investigations in criminal cases begins when the alleged criminal case enters the investigation and investigation stage. Management of the inquiry and investigation process is not only carried out by officials appointed by Law as referred to in the applicable laws and regulations, but management needs to be carried out by all parties, including the public, so that suspicion of criminal cases of corruption can not resolve. It decides to arrive at a court level that has permanent legal force.

\section{ACKNOWLEDGMENTS}

Thanks to the manager of the scientific journal Al-syir'ah Iain Manado who has published my journal.

\section{REFERENCES}

Arief, B. N. (2010). Bunga Rampai Kebijakan Hukum Pidana; Perkembangan Penyusunan Konsep KUHP Baru. Kencana.

Askin, M., \& Cahaya, S. (2008). Hukum Acara Pidana Di Luar KUHAP. Yayasan Gema Yustisia Indonesia.

Atmasasmita, R. (1995). Sistem Peradilan Pidana: Perspektif Eksistensialisme dan Abolisionisme. Bina Cipta.

Atmasasmita, R. (2003). Strategi Dan Kebijakan Pemberantasan Korupsi Pasca Konvensi PBB Menentang Korupsi.

CyberNews. (2011). Nilai Kerugian Negara Akibat Korupsi Rp 3,6 Triliun. Wordpress. https://antikorupsijateng.wordpress.com/2011/02/23/nilaikerugian-negara-akibat-korupsi-rp-36-triliun/

Ismail, D. E., \& Tamu, Y. (2009). Upaya PerlindunganHak-Hak Tersangka/Terdakwa Melalui Mekanisme Praperadilan Di Kota Gorontalo. Jurnal Mimbar Hukum, 21(1).

Isra, S., \& Hiariej, E. O. S. (2010). Perspektif Hukum Pemberantasan Korupsi di Indonesia dalam Korupsi Mengorupsi Indonesia. Gramedia. 
Mad. (2010). Susno Juga Didakwa Gelapkan Dana Pengamanan Pilgub Jabar Rp $8 M$. Detiknews. https://news.detik.com/berita/d-1451681/susno-jugadidakwa-gelapkan-dana-pengamanan-pilgub-jabar-rp-8-m-

Mertokusumo, S. (2010). Penemuam Hukum Sebuah Pengantar. Fakultas Hukum Universytas Atmadjaya.

Nasution, B. J. (2008). Metode Penelitian Ilmu Hukum. Bandar Maju.

NRL. (2013). Kronologi Kasus Susno: “Cicak vs Buaya” Hingga Dijebloskan ke LP Cibinong. Detiknews. https://news.detik.com/berita/d-2237058/kronologikasus-susno-cicak-vs-buaya-hingga-dijebloskan-ke-lp-cibinong

Ramelan. (2004). Penegakan hukum Tindak Pidana Korupsi dan Upaya Kejaksaan Memenuhi Ekspetasi Publik. Universitas Sebelas Maret.

Rukmini, M. (2006). Aspek Hukum Pidana dan Kriminologi (Sebuah Bunga Rampai). Alumni.

Soekanto, S. (2001). Pengantar Penelitian Hukum. Universitas Indonesia Press. 